\title{
Continuous Endothelial Cell Activation Increases Angiogenesis: Evidence for the Direct Role of Endothelium Linking Angiogenesis and Inflammation
}

\author{
Gangaraju Rajashekhar $^{a, b}$ Antje Willuweit ${ }^{\mathrm{e}}$ Carolyn E. Patterson $^{\mathrm{a}, \mathrm{b}, \mathrm{c}}$ \\ Peichuan Sun ${ }^{a, b}$ Andreas Hilbig ${ }^{e}$ Georg Breier $^{f}$ Armin Helisch $^{d}$ \\ Matthias Clauss ${ }^{a, b}$ \\ ${ }^{\mathrm{a}}$ Department of Cellular and Integrative Physiology, and ${ }^{\mathrm{b}}$ Indiana Center for Vascular Biology and Medicine, \\ Indiana University School of Medicine, ${ }^{\mathrm{C}}$ Roudebush VA Medical Center, Indianapolis, Ind., \\ ${ }^{\mathrm{d}}$ Dartmouth-Hitchcock Medical Center, Lebanon, N.H., USA; ${ }^{\mathrm{e}}$ Max-Planck-Institute, Bad Nauheim, and \\ ${ }^{\mathrm{f}}$ Institut für Pathologie, Universitätsklinikum Carl Gustav Carus, Dresden, Germany
}

\section{Key Words}

Angiogenesis · Inflammation • Endothelial dysfunction • Intracellular adhesion molecule $1 \cdot$ Matrigel plug assay • Reactive oxygen species - Tumor necrosis factor- $\alpha$

\begin{abstract}
There is increasing evidence that chronic inflammation is tightly linked to diseases associated with endothelial dysfunction, including the induction of aberrant angiogenesis. While leukocytes have been described as mediators of inflammation-associated angiogenesis, the effects of direct chronic endothelial activation have not been addressed in this context. Using an uncleavable mutant of the transmembrane form of tumor necrosis factor- $\alpha$ (TNF- $\alpha$ ), we have established models of stable TNF- $\alpha$ expression in endothelial cells in vitro and in transgenic mice in vivo. In the in vitro model, continuous endothelial activation leads to increased leukocyte cellular adhesion molecule expression and intracellular reactive oxygen species, hallmarks of a proinflammatory and dysfunctional endothelium. In addition, stable ex-
\end{abstract}

pression of TNF- $\alpha$ in endothelial cells increased angiogenic sprout formation in the presence but also in the absence of angiogenic growth factors. The partial neutralization of this effect by TNF- $\alpha$ antibodies and the inability of conditioned media from stable TNF- $\alpha$-expressing endothelial cells to induce angiogenic activities in control endothelial cells suggest that this effect does not require expression of additional autocrine factors, but is an autonomous effect of the transmembrane TNF on the endothelial cells. Furthermore, using the Matrigel plug assay in vivo, increased angiogenesis was observed in endothelial TNF- $\alpha$-expressing transgenic versus control mice. In conclusion, chronic inflammatory changes mediated by TNF- $\alpha$ can induce angiogenesis in vitro and in vivo, suggesting endothelial cell activation as a direct link between inflammation and angiogenesis.

Copyright (C) 2006 S. Karger AG, Basel

\section{KARGER}

Fax +4161306 1234 E-Mail karger@karger.ch www.karger.com (c) 2006 S. Karger AG, Basel 1018-1172/06/0432-0193\$23.50/0

Accessible online at: www.karger.com/jvr
Matthias Clauss, $\mathrm{PhD}$, Assoc. Prof.

Indiana Center for Vascular Biology and Medicine

975 W Walnut St; IB433

Indianapolis, IN 46202 (USA)

Tel. +1 317278 2837, Fax +1 317278 0089, E-Mail mclauss@iupui.edu 


\section{Introduction}

Endothelial cell activation is essential for many vascular pathologic processes, leading to inflammation, vascular remodeling, and vessel growth. In diseases associated with chronic inflammation, such as atherosclerosis, endothelial activation plays a role in both initiation and prolongation and exacerbation of the pathology. Such chronic endothelial activation is accompanied by endothelial dysfunction, characterized by sustained expression of leukocyte adhesion molecules, and thus, sustained leukocyte involvement, vascular permeability, dysregulation of vasoreactivity, a thrombogenic propensity, abnormal blood vessel remodeling, and, last but not least, angiogenesis [1]. Angiogenesis, the process of new blood vessel formation, is essential for embryonic growth, wound healing, the female reproductive cycle, and pregnancy in physiological settings [2, 3]. In contrast, excessive angiogenesis is noted in tumors, rheumatoid arthritis, atherosclerosis, psoriasis, obesity, inflammatory bowel disease, primary pulmonary hypertension, diabetic retinopathy, asthma, and advanced macular degeneration of the eye $[3,4]$.

The finding that inflammation is often associated with increased angiogenesis was explained by inflammationinduced production of angiogenic factors, either from vascular or other tissue cells, or from infiltrating leukocytes. Proinflammatory mediators, such as tumor necrosis factor- $\alpha$ (TNF- $\alpha)$, are known to activate the endothelium and increase expression of adhesion molecules and chemokines, which are critical steps for leukocyte recruitment [1]. These recruited leukocytes can mediate angiogenesis by release of endothelial growth factors [5-7]. However, there is insufficient experimental study of the precise mechanisms in chronic situations and it is unknown to what extent leukocyte-independent mechanisms also contribute to the angiogenesis. For instance, acute endothelial cell activation by TNF- $\alpha$ can elicit diverse effects dependent upon the state of the cells and other factors present. An anti-angiogenic role of TNF- $\alpha$ was suggested by the ability of soluble TNF- $\alpha$ receptor antibodies to increase endothelial cell proliferation [8]. In contrast, stimulation of angiogenesis by TNF was observed in the presence of either vascular endothelial growth factor (VEGF) or basic fibroblast growth factor (bFGF) [9], which was suggested to be mediated by activation of urokinase-type plasminogen activator. However, the role of TNF or other proinflammatory molecules in directly influencing angiogenesis in chronic diseases is not known, despite the fact that TNF- $\alpha$ and the TNF- $\alpha$ receptor superfamily are strongly implicated in a number of chronic diseases [10-14].

TNF- $\alpha$, the founding member of the TNF family of cytokines, is produced as a transmembrane spanning precursor protein $(\operatorname{tmTNF}-\alpha)$ and a proteolytically cleaved soluble form. Given the correlation of soluble TNF- $\alpha$ concentration in plasma with infectious and inflammatory diseases, it is understandable that this form was soon perceived as the natural form of TNF- $\alpha$, while the transmembrane form being present or induced on a variety of immune and non-immune cells (including endothelial cells) was widely disregarded. However, more recently, a variety of conditions that activate endothelial cells have been convincingly shown to express tmTNF- $\alpha$ in vitro and in vivo [15-22]. Despite the exponential awareness of the critical role for endothelial activation in many diseases, there is a dearth of models to study the initiating disease potential and direct effects of continuous endothelial activation. In order to mimic the situation of chronic activated endothelium, we have established models of stable $\mathrm{TNF}-\alpha$ expression in endothelial cells in vitro and in transgenic mice in vivo using an uncleavable mutant of TNF- $\alpha$.

Using these specific models, we demonstrated an increase in cell adhesion molecules and reactive oxygen species (ROS) as a measure of continuous activated endothelium, a significant increase in sprout formation as a measure of in vitro angiogenesis, and increased neovascularization in Matrigel plugs as a measure of in vivo angiogenesis. Thus, in this study, we show that angiogenesis could be induced per se by activated endothelium, establishing a direct link between inflammation and angiogenesis.

\section{Materials and Methods}

\section{Antibodies and Reagents}

Neutralizing antibodies to TNF (clone MP6-XT3) and TNF receptor type I (TNFRI; clone 55R-170) were purchased from BD Biosciences, San Jose, Calif., and R\&D Systems, Minneapolis, Minn., USA, respectively. Murine CD31 (Mec13.3) was from Pharmingen, Oxford, UK, and murine CD34 (Mec14.7) was from Sanbio, Beutelsbach, Germany. The hybridomas 25ZC7 (anti-intercellular adhesion molecule 1; anti-ICAM-1) [23], 6C7 and 4B12 (anti-vascular cell adhesion molecule 1; anti-VCAM-1) [24] were a kind gift of D. Vestweber (Münster, Germany). The Matrigel was purchased from BD Biosciences, Heidelberg, Germany, while bFGF was from R\&D Systems, Wiesbaden, Germany, and VEGF 165 (heparin-binding VEGF $_{165}$ isoform also known as VEGF-A) was from ReliaTech, Braunschweig, Germany. 2',7'-dichlorodihydrofluorescein diacetate (H2DCFDA) and dihydroethidium (DHE) were from Molecular Probes, Eugene, Oreg., USA. DMEM, FCS, 
antibiotics, apocynin, soluble TNF- $\alpha$, and thrombin were from Sigma Chemical Co., St. Louis, Mo., USA. Trolox was purchased from Calbiochem, La Jolla, Calif., USA.

Generation of tmTNF- $\alpha$-Expressing Endothelial Cells

Polyoma virus middle T-transformed endothelial cells from wild-type newborn mice were kindly provided by F. Kiefer (Münster, Germany) [25] and cultured in DMEM supplemented with $10 \%$ FCS, $2 \mathrm{~m} M$ glutamine, and $1 \times$ penicillin/streptomycin. Cells were transfected with the uncleavable transmembrane mutant form of murine TNF- $\alpha[\mathrm{mTNF} \alpha \Delta 1-9, \mathrm{~K}(11) \mathrm{E}]$ [26] by retroviral gene transfer. The cDNA for $\mathrm{mTNF} \alpha \Delta 1-9, \mathrm{~K}(11) \mathrm{E}$ [27] was cloned into the $\mathrm{pBABE} / \mathrm{neo}$ vector [28] and stably transfected into the retrovirus packaging cell line GP+E86 [29]. Culture supernatants of transfected GP+E86 cells supplemented with $8 \mu \mathrm{g} / \mathrm{ml}$ polybrene were used for infection of endothelial cells for $3 \mathrm{~h}$. Infected endothelial cells were selected with gentamycin-containing medium $(1 \mathrm{mg} / \mathrm{ml})$. Endothelial cells transfected with the empty vector were treated identically and used as control cells.

\section{Flow Cytometric Analysis of Cell Adhesion Molecules}

Cytofluorometric analysis (FACS) was performed as previously described [18]. Both control and tmTNF- $\alpha$-expressing endothelial cells were cultured to confluency, detached using EDTA buffer, and incubated with primary antibodies - hybridoma supernatant immunoglobulin $\mathrm{G}(\mathrm{IgG})$ in phosphate buffer supplemented with $2.5 \%$ FCS and $0.02 \%$ sodium azide - for $30 \mathrm{~min}$ at $4{ }^{\circ} \mathrm{C}$. After washing, cells were incubated with phycoerythrin-conjugated secondary antibody (Dianova, Hamburg, Germany) and analyzed on a FACStar using CellQuest software (Becton Dickinson, Heidelberg, Germany) drawing light scatter gates around live endothelial cell populations.

\section{Real-Time Analysis of Intracellular ROS Production}

H2DCFDA is a commonly used dye that allows the monitoring of intracellular ROS production in general, regardless of the precise enzymatic or non-enzymatic source, as it is oxidized by a number of oxidant species, including nitric oxide (NO) [30]. This method is based on the uptake and intracellular hydrolysis of the H2DCFDA dye by intracellular esterases to the non-fluorescent derivative, $\mathrm{DCFH}$, which is polar and trapped within the cells. Confluent endothelial cells in 96-well black-walled plates were incubated in DMEM and $10 \mu M$ H2DCFDA for 30 min to allow intracellular uptake. Cells were washed 3 times and media replaced (without dye but with $1 \%$ albumin). Fluorescence of the oxidized dye was subsequently determined at $495 \mathrm{~nm}$ (excitation), $525 \mathrm{~nm}$ (emission), with $515 \mathrm{~nm}$ cutoff on a Flex station set for maximal detection in monolayer cells compared with dye alone. Non-specific background fluorescence (no dye) was not different between groups (different cell treatments or different inhibitor additions) and was subtracted to give specific relative fluorescence units. In order to verify that the oxidation of DCFH was dependent on ROS production, an inhibition dose response to the radical scavenger, Trolox, was determined with an inhibitor present throughout dye loading, washing, and the subsequent assay. As DCFH oxidation responds to NO as well [31], we also examined the inhibition in the presence of the NO synthase inhibitor, $\mathrm{N}^{\mathrm{G}}$-nitro- $L$-arginine methyl esther $(L$ NAME). To assess the relative contribution of NAPDH oxidase to ROS formation, we analyzed the oxidation of DHE to ethidium, which is more specific for superoxide, in the presence and absence of several concentrations of the NAPDH oxidase inhibitor, apocy- nin. Cells were loaded 30 min with $5 \mu M$ DHE, washed, and media replaced as for DCFH. Ethidium oxidization was determined on the Flex Station at $520 \mathrm{~nm}$ (excitation), $605 \mathrm{~nm}$ (emission), with $595 \mathrm{~nm}$ cutoff.

\section{In vitro Sprout Formation Assay}

Angiogenesis in vitro was tested as described previously, with slight modifications [32]. Briefly, the endothelial cells were grown to confluence on cytodex-3 microcarrier beads (Sigma) and placed into a 12-well culture plate (Nalge Nunc Int., Rochester, N.Y., USA) containing fibrinogen gel. Polymerization was started by adding $0.48 \mathrm{U} / \mathrm{ml}$ thrombin. About $1 \mathrm{ml}$ of the media with or without factors of interest was added to each well and incubated for $1 \mathrm{~h}$ at $37^{\circ} \mathrm{C}, 5 \% \mathrm{CO}_{2}$. After $1 \mathrm{~h}$, the media was replaced with fresh media with the respective factors and incubation was continued. After $24 \mathrm{~h}$, the gel was fixed in $1 \%$ paraformaldehyde and the number of sprouts per 50 beads longer than the average bead size was counted under a phase contrast microscope. No significant morphological differences were noted between controls and tmTNF cell sprouts. Experiments were performed in triplicate and repeated at least four times. For inter-individual observational differences, the number of sprouts was also counted by a person blinded to the study design.

\section{Tie2-tmTNF Transgenic Animals}

The construction of transgene and the generation of Tie2tmTNF transgenic animals were described previously [27]. These mice contain the cDNA of the uncleavable mTNF $\alpha \Delta 1-9, \mathrm{~K}(11) \mathrm{E}$ cloned between endothelial-specific Tie2 promoter and the Tie2 first intron in order to localize TNF- $\alpha$ specific to the endothelium. Mice used for this study had been back-crossed for more than eight generations in C57BL/6 animals. Mice were used as heterozygous for the transgene, and non-transgenic litter mates served as wildtype controls.

\section{Angiogenesis in vivo/Matrigel Plug Assay}

A modified method of the Matrigel plug assay described by Passaniti et al. [33] was used to assess angiogenesis in Tie2-tmTNF transgenic mice and non-transgenic littermates. Briefly, Matrigel was mixed with $200 \mathrm{ng} / \mathrm{ml} \mathrm{bFGF}$ and $500 \mathrm{ng} / \mathrm{ml} \mathrm{VEGF}_{165}$, and $0.4 \mathrm{ml}$ were subcutaneously injected into mice. After 14 days, Matrigel plugs were harvested, fixed in 1\% paraformaldehyde for $4.5 \mathrm{~h}$ on ice, and embedded in paraffin. After deparaffination, alternate $6-\mu \mathrm{m}$ sections from the center of the excised Matrigel plugs were stained with rat monoclonal antibodies to CD31 and CD34. Sections were developed after incubation with a biotin-conjugated goat anti-rat IgG secondary antibody (Dianova, 1:100) using the vectastain Elite ABC Kit (Vector Laboratories, Burlingame, Calif., USA) and the AEC Chromogen Kit (Sigma) according to the manufacturers' instructions. Stained cells were counted in several sections and high-power fields (at least 20/animal), and the amounts of CD31- or CD34-positive cells were calculated.

\section{Statistical Analysis}

Data are expressed as mean \pm SD for each group, performed in triplicate for in vitro sprout assay and for the measurement of ROS production. Statistical significance was determined by ANOVA using the Microsoft Excel Statistical Package and by Welch's $t$ test using InStat software for the in vivo Matrigel plug assay. A probability value $\mathrm{p}<0.05$ was considered statistically significant. 


\section{Results}

tmTNF- $\alpha$ Overexpression in Endothelial Cells Leads to Continuous Expression of Intercellular Adhesion Molecules

We have previously reported that transfection of immortalized macrovascular human umbilical cord vein endothelial cells with a transmembrane uncleavable mutant form of TNF- $\alpha$ leads to continuous activation of proinflammatory signal transduction pathways (p38 mitogenactivated protein kinase and nuclear factor $-\kappa \mathrm{B}$ ) and tissue factor production [18]. Here, we stably transfected polyoma middle $\mathrm{T}$ immortalized murine endothelial cells, which are of microvascular appearance, with the transmembrane uncleavable mutant form of TNF- $\alpha$ using retroviral gene transfer. Expression of TNF- $\alpha$ in these cells was demonstrated by FACS analysis, whereas vector-only transfected control cells did not stain for TNF- $\alpha$ (data not shown). Using FACS analysis, the expression of vascular adhesion molecules in tmTNF- $\alpha$-expressing endothelial cells was compared with control cells. In addition, both control cells and tmTNF- $\alpha$ stable transfected cells were treated with soluble TNF- $\alpha$ at $1 \mathrm{n} M$ for $12 \mathrm{~h}$. Cells stimulated with soluble TNF- $\alpha$ (dark histogram) or untreated (bright histogram) were incubated with antibodies directed against VCAM- 1 or ICAM- 1 as indicated. In tmTNF- $\alpha$ expressing endothelial cells, the signals for ICAM-1 and VCAM-1 shift to the right indicating increased expression, whereas in control cells, they remain at basal levels (fig. 1). This implies that the stable transfected tmTNF- $\alpha$ cells display constitutively increased levels of ICAM-1 and VCAM-1 at the surface in comparison with control cells. Stimulation with soluble TNF- $\alpha$ strongly induces VCAM-1 and ICAM-1 surface expression in control cells, but no further significant upregulation can be seen in tmTNF- $\alpha$ expressing endothelial cell. These findings indicate that continuous endothelial cell activation leads to continuous and stable expression of vascular adhesion molecules, which mediate both acute and chronic inflammation.

\section{Increased ROS Concentrations in Endothelial Cells}

Expressing tmTNF- $\alpha$

Another hallmark of activated endothelium in chronic inflammation is the increased production of free ROS. Soluble TNF- $\alpha$ is known to induce the formation of ROS, which results from NADPH oxidase activation, but also induces increased expression of specific members of the NADPH oxidase complex, such as the gp91 ${ }^{\text {phox }}$ [34]. Based on our findings from gene expression studies in tmTNF- $\alpha$-expressing endothelial cells (unpublished data) that this subunit (NOX2 isoform) is increased 7-fold, we reasoned that these cells may show continuously increased ROS levels. When assessing intracellular ROS concentrations by oxidation of DCFH (a fluorescent substrate), we found increased concentrations in tmTNF- $\alpha$-expressing versus control endothelial cells, which was attenuated by the addition of the antioxidant Trolox (fig. 2a, b). As seen in the Trolox dose-response curve (fig. 2a), this inhibition is maximally $65 \%$, whereas higher levels of Trolox can actually increase the oxidant load and increase DCFH oxidation. This pro-oxidant effect at a higher concentration of anti-oxidants, such as vitamin $\mathrm{E}$, is well documented [35]. Notably, addition of the NO synthase inhibitor, L-NAME, further reduced DCFH oxidation (combined average inhibition of 97\%) indicating that NO-mediated dye oxidation accounted for the remainder of the DCFH fluorescence which was not inhibited by Trolox alone (fig. 2a). Next, we assessed the potential contribution of NADPH oxidase-derived superoxide to ROS accumulation in the tmTNF- $\alpha$ cells by analyzing apocynin-induced inhibition of ethidium oxidation, a more specific marker for superoxide generation [36]. Similar to the chronic increase in ROS production in general, as detected by DCFH oxidation, tmTNF- $\alpha$ expression significantly increased ethidium oxidation (fig. 2c). Apocynin only very modestly reduced the ethidium oxidation in control cells, indicating that most superoxide radicals were derived from other sources, such as the mitochondrial respiration, under basal condition in control cells. However, in the tmTNF- $\alpha$ cells, apocynin reversed 70\% of the gain over control. This indicates that chronic activation of NADPH oxidase in the tmTNF cells importantly contributed to the increased oxidant load. In conclusion, stable tmTNF- $\alpha$ expression leads to persistent activation in endothelial cells, which resembles a dysfunctional and proinflammatory phenotype.

\section{Enhanced Sprout Formation (Angiogenesis) in tmTNF- $\alpha$ Endothelial Cells}

Microvascular endothelial cells are believed to initiate sprouting angiogenesis, which is observed to be increased in chronic inflammatory diseases. In order to test the hypothesis that endothelial activation induces angiogenic activity, we assessed tmTNF- $\alpha$-expressing endothelial cells in an in vitro assay for angiogenesis. Endothelial cells grown on microcarrier beads were embedded into a fibrin gel in the presence or absence of VEGF to induce sprouting. Randomly 50 individual beads with sprouts longer than the average size of beads were counted in the presence $(2.5 \mathrm{ng} / \mathrm{ml})$ or absence of $\mathrm{VEGF}_{165}$. tmTNF- $\alpha$ endo- 


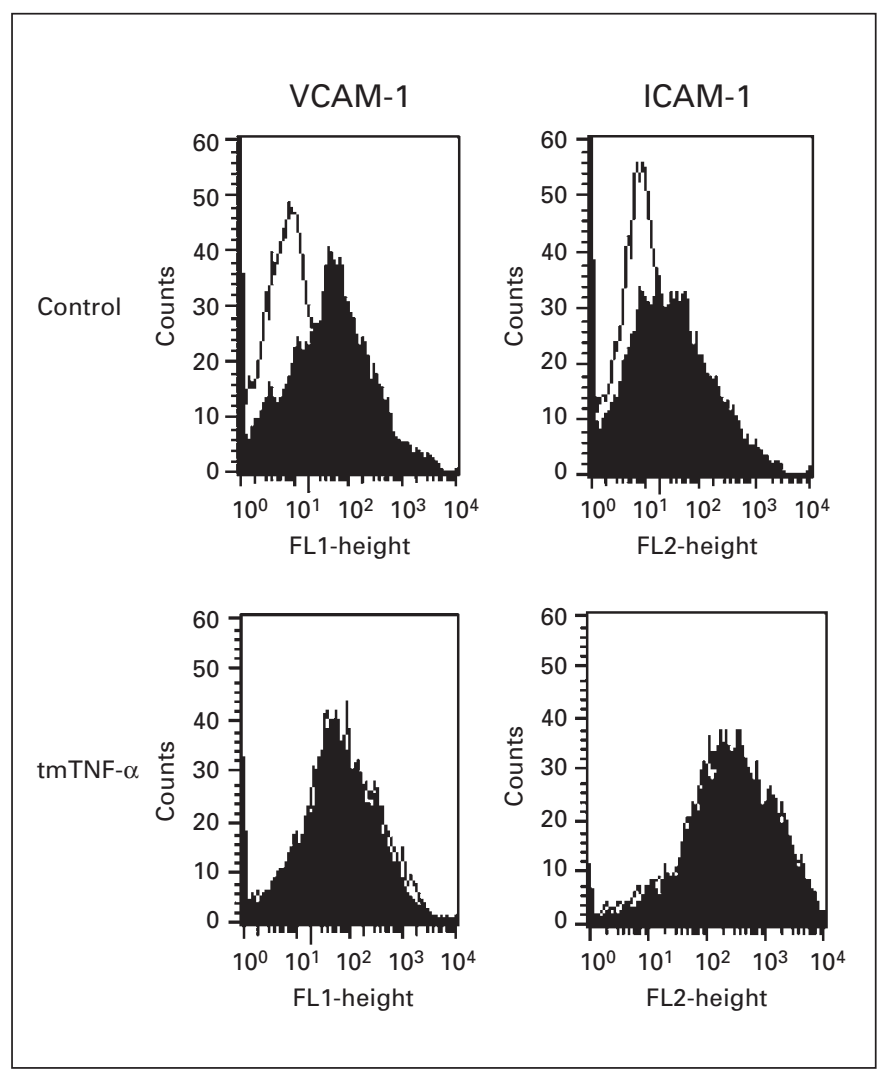

Fig. 1. Increased expression of ICAM-1 and VCAM-1 in tmTNF$\alpha$-expressing versus control endothelial cells. FACS analyses are shown of control and tmTNF- $\alpha$-expressing endothelial cells stained either with anti-ICAM-1 or VCAM-1 antibodies as described in 'Materials and Methods'. As a positive control, samples from cells treated with soluble TNF- $\alpha(1 \mathrm{n} M)$ for $12 \mathrm{~h}$ are displayed in dark, while untreated samples are shown in light colors. Of note, in tmTNF- $\alpha$-expressing cells, soluble TNF did not lead to significant further increase in ICAM-1 or VCAM-1 expression. Data shown are representative of experiments performed in duplicate and repeated at least four times with similar results.

Fig. 2. Increased ROS in tmTNF- $\alpha$-expressing endothelial cells. Confluent control or tmTNF- $\alpha$ endothelial cells were tested for ROS production. a Inhibition of DCFH oxidation, a marker of generalized oxidant production, in tmTNF cells by Trolox and by a combination of Trolox and $1 \mathrm{~m} M L$-NAME. Of note, while inhibition of ROS-mediated DCFH oxidation was prominent at lower levels, at higher levels, inhibition was less prominent, suggesting a pro-oxidant activity at the higher concentrations. ${ }^{a} \mathrm{p}<0.05$ : significant difference from no inhibitor; ${ }^{b} \mathrm{p}<0.05$ : significant difference from Trolox alone at same dose. $\mathbf{b}$ ROS production, measured by DCFH oxidation, is increased in tmTNF- $\alpha$ cells compared with controls, and oxidant stress was significantly inhibited in both with

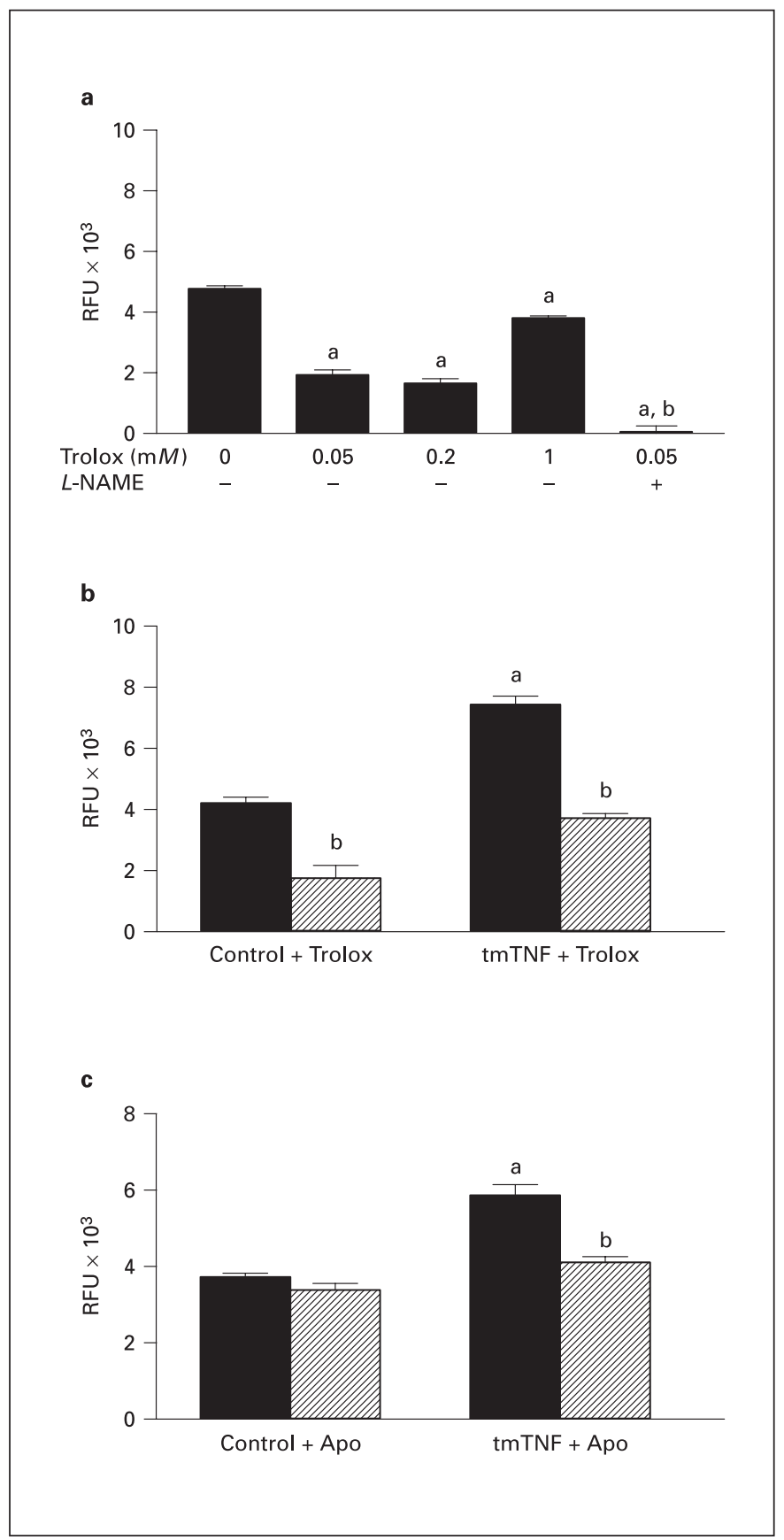

Trolox $(0.2 \mathrm{mM}) .{ }^{\mathrm{a}} \mathrm{p}<0.05$ : significant difference versus control cells; ${ }^{b} \mathrm{p}<0.05$ : significant difference versus same cell treatment with/without inhibitor. c Fluorescence of oxidized ethidium, a more specific measure of superoxide production, demonstrates significantly increased superoxide radicals in tmTNF cells versus control cells $\left({ }^{\mathrm{a}} \mathrm{p}<0.05\right)$. Inhibition of NADPH oxidase by apocynin (Apo) $(0.1 \mathrm{~m} M)$ resulted in a significant attenuation $\left({ }^{b} \mathrm{p}<0.05\right)$, indicating that NADPH oxidase is a major contributor to the gain in superoxide levels over control. Similar inhibition was found with 0.5 and $2 \mathrm{~m} M$ apocynin (data not shown). All experiments were performed in replicates (4-8), and experiments were repeated at least two additional times. RFU $=$ Relative fluorescence unit. 

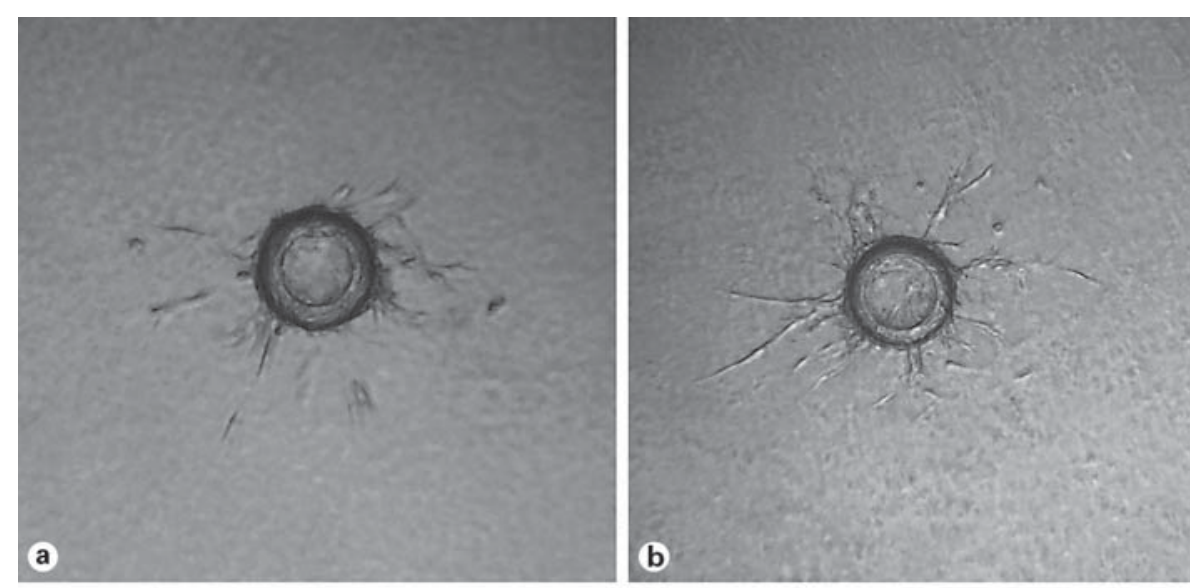

Fig. 3. Enhanced sprout formation (angiogenesis) in tmTNF- $\alpha$ endothelial cells. A representative phase contrast micrograph of endothelial cell-coated cytodex beads depicting the sprouts of control cells in the absence (a) or presence (b) of VEGF and tmTNF- $\alpha$-expressing cells in the absence (c) or presence (d) of VEGF. e Angiogenic sprouting activity in control ( $\square$ ) and tmTNF ( $\square$ ) endothelial cells embedded in fibrin gels was quantified. tmTNF endothelial cells demonstrated a significant $\left({ }^{a} p<0.01\right)$ increase in capillary-like sprouts (mean $\pm \mathrm{SD}$ ) as compared with control cells, indicating an independence from growth factors. An additive increase in sprouting activity was observed with VEGF addition in the tmTNF- $\alpha$ cells $\left({ }^{b} \mathrm{p}<0.05\right)$. The data presented are from a representative experiment repeated four times independently with similar results.
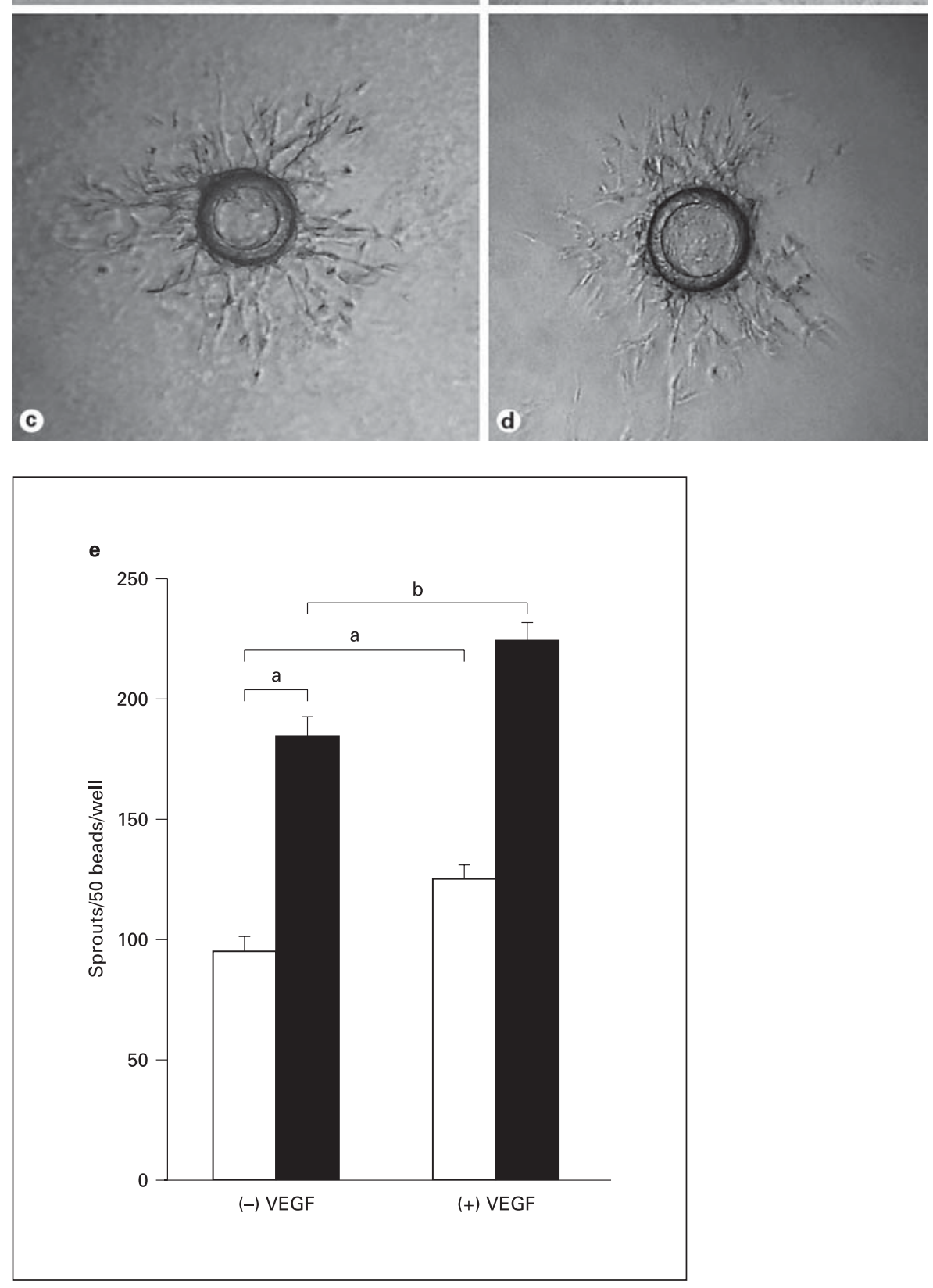
Fig. 4. Angiogenic effect of stable tmTNF- $\alpha$ expression is direct. Control endothelial cells or stable tmTNF- $\alpha$-transfected cells were seeded on cytodex- 3 beads and embedded into a 3-dimensional fibrin gel to determine sprouting. a CM collected from tmTNF- $\alpha$ endothelial cells were added to control cells. No significant change in sprout numbers was observed. b Conversely, CM from control cells was added to stable tmTNF- $\alpha$-transfected cells. Again, no significant changes in sprout numbers were observed. c Neutralizing antibodies to TNF, TNFRI, or isotype-matched IgGs were added to the media during the duration of the sprout formation assay. Note a significant decrease in sprout numbers (mean $\pm \mathrm{SD}$ ) with anti-TNF as well as antiTNFRI $\left({ }^{\mathrm{a}} \mathrm{p}<0.05\right)$ but not isotype-matched control ( $\left.{ }^{b} \mathrm{p}>0.05\right)$. The data presented are from a representative experiment repeated four times independently with similar results.
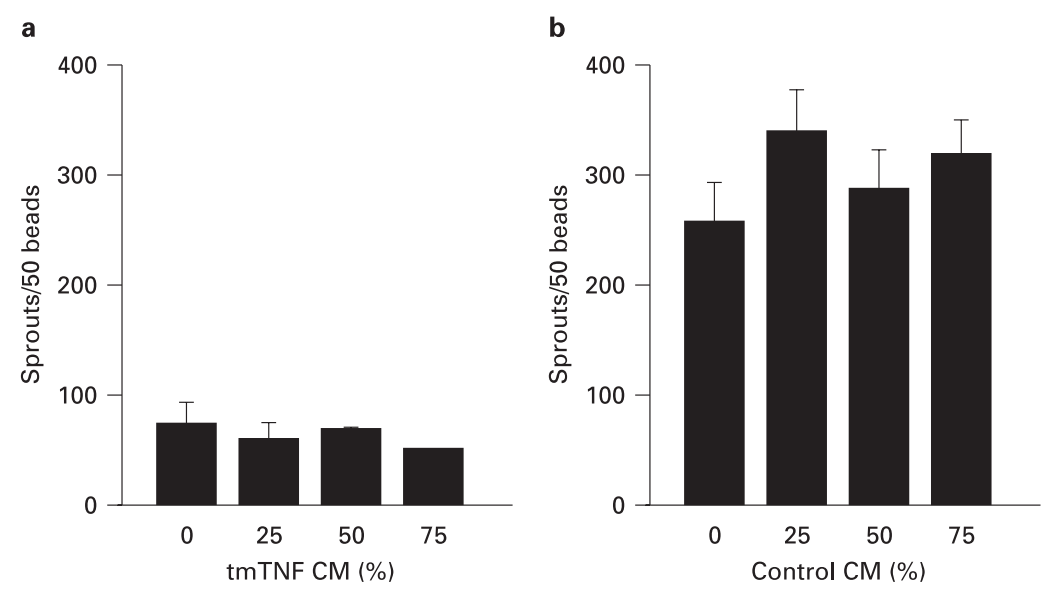

c

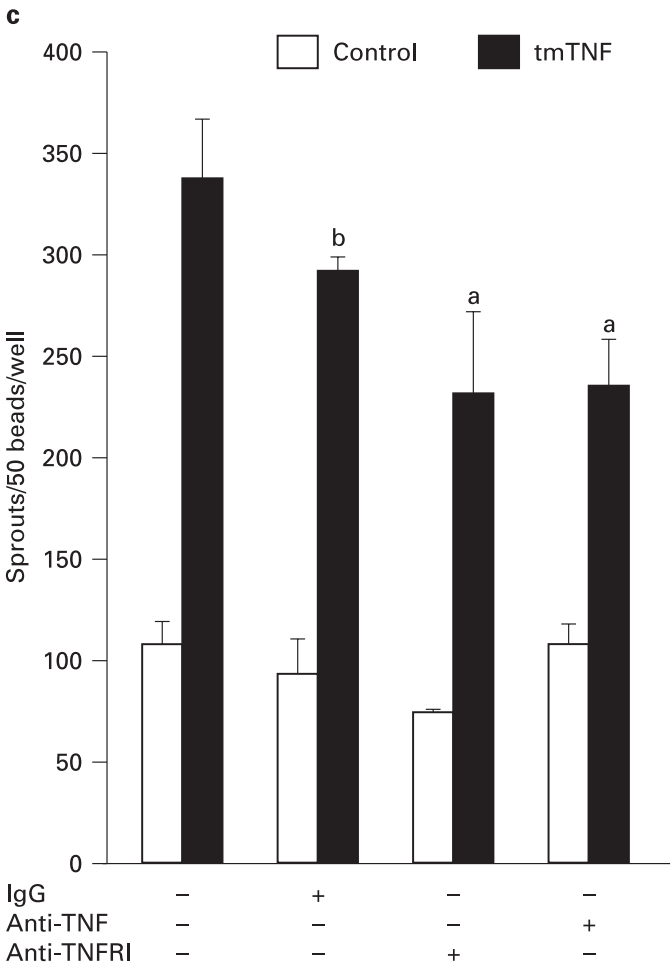

thelial cells demonstrated a significant $(p<0.05)$ increase in capillary-like sprouts as compared with control clones (fig. 3). This effect was comparable with the effects of VEGF alone on control cells, indicating that these cells become independent from requirement for exogenous growth factor-induced angiogenesis, although growth factor addition caused a further, additive increase in angiogenesis in vitro (fig. 3).
The Angiogenic Effect of Stable tmTNF- $\alpha$ Expression Is Direct

To further explore whether this angiogenic effect of stable tmTNF expression is due to the release of growth factors or to a direct effect on endothelial signaling, we have performed experiments quantifying the effect of conditioned media (CM) on endothelial sprouting (fig. 4). Both control and tmTNF cells were seeded in T75 flasks 

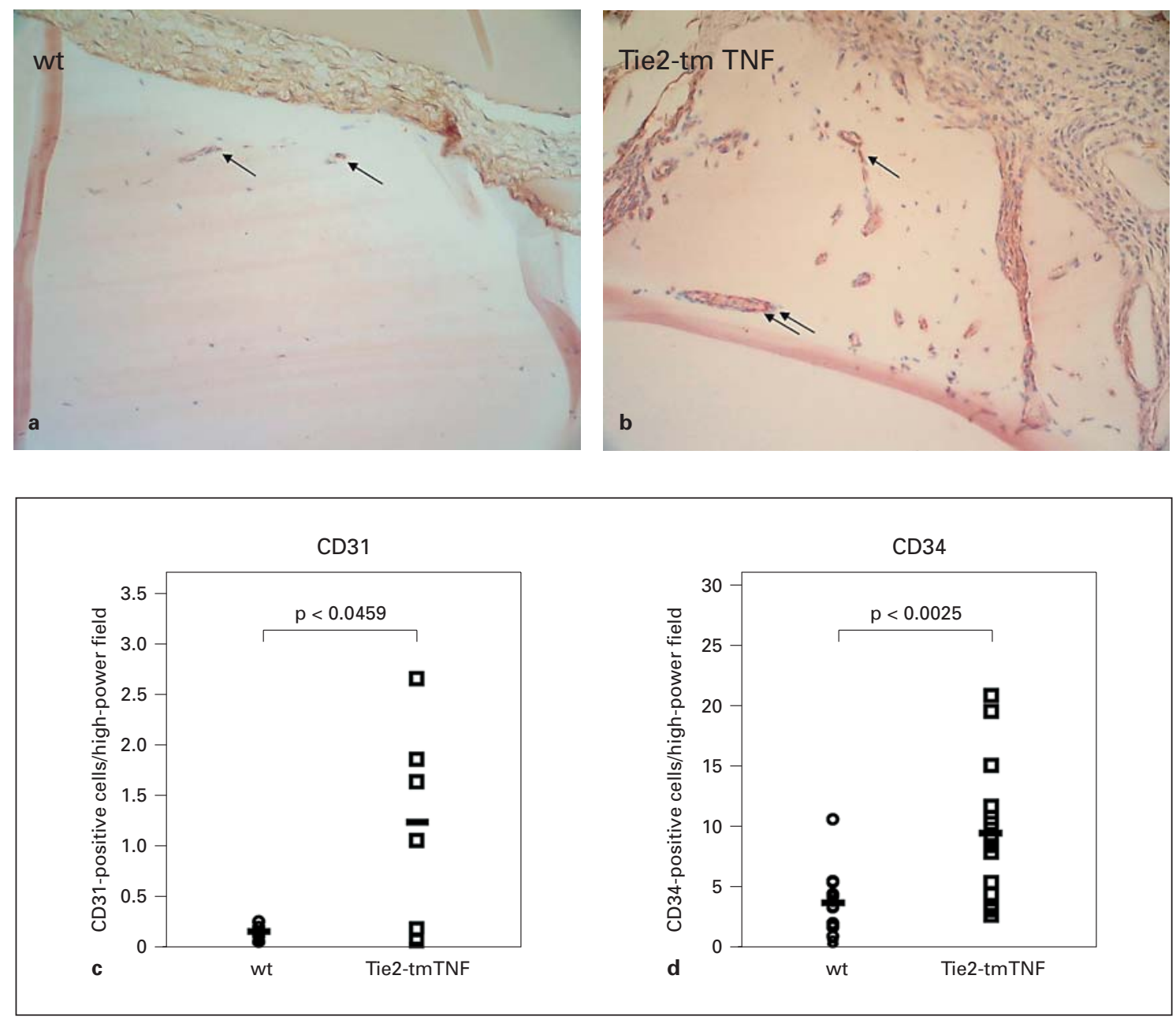

Fig. 5. Increased angiogenesis in vivo in endothelial TNF- $\alpha$-expressing Tie2-tmTNF mice. Matrigel solutions, supplemented with VEGF and FGF, were injected subcutaneously under the skin of 8-week-old animals. Matrigel plugs were excised after 2 weeks from 8 Tie2-tmTNF transgenic and 6 wild-type animals and embedded into paraffin. a, b Sections, stained with anti-CD34 antibodies, from wild-type (wt) and transgenic (Tie2-tmTNF) animals. Whereas in control animals only very few CD34-positive cells in vessel-like structures were found (a; arrows), in sections from Tie2-tmTNF mice, many vessel-like structures, positive for CD34, were observed (b). One vessel shows CD34-positive stain in the inner lining of a vascular-like structure (double arrow), whereas cells surrounding this structure only show blue H\&E stain. Another microvessel-like CD34-positive structure reveals a sproutlike appearance (single arrow). c, d Quantification of cells/high-power fields in sections stained with antibodies against the endothelial selective markers CD31 (c) and CD34 (d) in Tie2-tmTNF and wild-type mice.

at 5,000 cells $/ \mathrm{cm}^{2}$ (about $10 \%$ confluency) and cultured to confluency for up to 4 days. The supernatant was collected, centrifuged, and labeled as CM. Sprout formation was assessed with the addition of increasing concentrations of $\mathrm{CM}$ from control cells to stable tmTNF $\alpha$-transfected cells and vice versa. As shown in figure $4 \mathrm{a}$, control cells treated with $\mathrm{CM}$ from tmTNF- $\alpha$ cells showed no increase in sprout formation, indicating that there were no stimulatory growth factors released by tmTNF- $\alpha$ endothelial cells. Conversely, as shown in figure $4 b$, no significant changes in sprout formation occurred in tmTNF- $\alpha$ cells treated with CM from control cells, excluding the secretion of inhibitory factor from control cells. Thus, the overall increased sprout formation seen in tm TNF- $\alpha$ cells as compared with control cells is indeed due to an autonomous signal effect of tmTNF- $\alpha$ rather 
than to an indirect autocrine-like effect by secretion of growth factors. Furthermore, neutralizing antibodies to either TNF- $\alpha(5 \mu \mathrm{g} / \mathrm{ml})$ or TNFRI $(10 \mu \mathrm{g} / \mathrm{ml})$, but not isotype-matched $\mathrm{IgG}$, significantly reduced sprout formation in tmTNF- $\alpha$ cells, further supporting the direct angiogenic role for tmTNF- $\alpha$ (fig. $4 c$ ).

\section{Increased Vessel Growth in Tie2-tmTNF Mice}

Next, we wanted to test in vivo whether endothelial cell activation mediated by stable transfection with $\mathrm{TNF}-\alpha$ causes increased angiogenesis. In this assay, Matrigel solutions, incorporating growth factors (VEGF and FGF-2), were injected under the skin of Tie2-tmTNF transgenic and wild-type animals. After 2 weeks, neovascularization was quantified in sections by immunostaining with CD31 and CD34, established markers for increased angiogenesis [37-40]. As shown in figure 5a and $b$, several cellular infiltrates, CD34-positive structures, resembling blood vessels (arrows) can be seen in plugs from transgenic mice, whereas only few such structures are visible in wild-type animals. Quantification of invading endothelial cells by use of the two markers CD31 and CD34 indicated significantly higher neovascularization in Tie2-tmTNF transgenic versus wild-type mice (fig. 5c, d).

\section{Discussion}

The present study demonstrates that continuous endothelial activation can lead to angiogenesis in vivo (Matrigel plug assay) and, in the complete absence of leukocytes, in vitro (sprout assay). Although recruitment of leukocytes is known to be a critical feature in pathologic instances of angiogenesis, which in turn is dependent on expression of endothelial adhesion molecules and/or on chemokines, here, we show that angiogenesis can occur directly with endothelial cell activation, apart from the complementary angiogenic effects of leukocytes. Importantly, this direct angiogenic effect of continuous endothelial cell activation also occurs in the absence of added growth factors in vitro.

Based on our and other studies, showing tmTNF- $\alpha$ to be upregulated in the highly angiogenic MethA fibrosarcoma of mice [18] as well as in neovessels of atherosclerotic plaques [41], we hypothesized that tmTNF- $\alpha$ contributes to pathological angiogenesis. In this study, using the in vivo Matrigel model of angiogenesis, increased cellular infiltrates positive for the endothelial markers CD31 and CD34 could be observed in plugs from trans- genic mice versus wild-type animals, suggesting that TNF- $\alpha$-elicited endothelial cell activation may contribute to angiogenesis in vivo. Although it is generally assumed that the endothelial marker CD31 is endothelial specific [37], it can also be found on tumor-infiltrating macrophages and lead to an overestimation of angiogenesis [42]. Therefore, we confirmed our results using another marker, CD34, which is established in angiogenic vessels and absent on monocytes/macrophages [39]. Our finding that there are more CD34-positive than CD31positive cells in the Matrigel plug assay of transgenic animals may be explained by higher numbers of CD34, Flk-1- and AC133-positive endothelial progenitor cells, which may not be fully differentiated into endothelial cells as reported previously [43]. In addition, this finding of more CD34 versus CD31 cells is unlikely to be explained by CD34-positive leukocytic precursor cells as we did not observe leukocyte infiltration. Furthermore, both leukocytes and platelets can express CD31, so infiltration does not account for the higher number of CD34-positive cells. This is important in light of the assumption that proinflammatory cells including macrophages modulate angiogenesis as growth factor-releasing cells [44]. However, this is not likely to be the cause of the stimulated angiogenesis in our assays since we have incorporated high concentrations of VEGF and bFGF into the Matrigel.

In further support of the hypothesis that the angiogenic activity observed within the Matrigel plug assay is mediated by a direct effect of tmTNF- $\alpha$-expressing endothelial cells and not by leukocytes, we tested tmTNF- $\alpha$ expressing endothelial cells in an in vitro assay for angiogenesis. It has previously been shown that this assay is suitable to study a variety of growth factors in vitro [45, 46], and we demonstrated coherence of this assay with in vivo angiogenesis $[32,38]$. When control endothelial cells were stimulated with VEGF, increased sprout formation was observed, similar to that which we previously demonstrated with other microvascular endothelial cells [32]. In this study, tmTNF- $\alpha$-expressing endothelial cells showed significantly more sprout formation than control cells. This effect was comparable with the increase observed with an optimal concentration of VEGF. Interestingly, sprout formation in tmTNF- $\alpha$-expressing endothelial cells in the presence of VEGF was further increased. The observed increase in angiogenic activity of tmTNF- $\alpha$-transfected endothelial cells could possibly be explained by a difference in signaling pathways, which renders tmTNF- $\alpha$-activated endothelial cells proangiogenic and independent from a requirement for stimula- 
tion with angiogenic growth factors. Furthermore, by adding $\mathrm{CM}$ from tmTNF cells onto control cells and vice versa from control cells onto tmTNF- $\alpha$-expressing cells, we demonstrated that neither secretion of angiogenic factors from tmTNF- $\alpha$-expressing cells nor release of inhibitory factors from control cells could explain the observed angiogenic difference between stable tmTNF- $\alpha$-expressing and control cells. In conclusion, together with the neutralizing anti-TNF- $\alpha$ antibody data (fig. $4 \mathrm{c}$ ), we have provided evidence for the hypothesis that tmTNF- $\alpha$ acts as a direct stimulator of blood vessel growth in the sprout formation model of angiogenesis. Although the intracellular signaling pathways are not clear yet, these experiments open the possibility of a definitive role for tmTNF- $\alpha$ as a connecting link between inflammation and angiogenesis.

Previously, we have shown that in vitro tmTNF- $\alpha$ expression in human umbilical cord vein endothelial cells also caused an autonomous and continuous activation, exemplified by persistent p38 mitogen-activated protein kinase and nuclear factor- $\mathrm{kB}$ activation and by tissue factor and interleukin 6 production [18]. We also reported that Tie2-tmTNF (endothelial) expression in transgenic mice resulted in sustained expression of endothelial adhesion molecules for leukocytes in vivo [27]. In the present study, we demonstrate a stable and continuous surface expression of ICAM- 1 and VCAM- 1 on the surface of tmTNF- $\alpha$-expressing murine endothelial cells, confirming the earlier in vivo study on adhesion molecules [27]. Our results are in contrast to Canault et al. [47] who reported no significant increase in ICAM-1 in mouse aortic endothelial cells. There are several possibilities which may explain the observed differences. Microvascular endothelial cells used in this study compared with macrovascular endothelial cells used by Canault et al. [47] could contribute to the differences, as could the difference in the transgenic models being used. Additionally, in our studies of in vitro and in vivo models, endogenous production of soluble TNF- $\alpha$ is possible, whereas Canault et al. [47] express the uncleavable tmTNF- $\alpha$ mutant in the absence of any soluble TNF- $\alpha$ using TNF- $\alpha$ gene-deficient animals as 'genetic background'.

The elucidation of molecules and mechanisms underlying the continuous activated endothelium could provide new targets for drug development that spare the important infection-fighting activities of leukocytes and the physiologic beneficial role of local TNF- $\alpha$ production, but terminate untoward continuous endothelial activation and its resultant contribution to pathologic in- flammation and angiogenesis. For instance, the ability of TNF- $\alpha$ to induce VCAM-1 and ICAM-1 may not only enhance emigration of leukocytes but also angiogenesis by yet another pathway. This requires proteolytic conversion of these cellular adhesion molecules to their soluble forms, which have been shown to synergize with TNF- $\alpha$ in both in vitro and in vivo models of angiogenesis $[48,49]$. The supposition that selective signal transduction pathways, leading to expression of distinct vascular adhesion molecules, are involved in processes of chronic inflammation is of clinical relevance, because it could lead to the development of more specific blockers of pathways in the chronic activation, which differ from the acute activation sequence. Such remedies could be designed based on the ability to interfere with specific signal transduction pathways, leading to selective adhesion molecule expression.

Recently, ROS were identified as downstream mediators of angiogenic signaling by VEGF receptor 2/kinase insert domain receptor [50]. In this study, we found that oxidant production was significantly increased in the tmTNF- $\alpha$ cells, indicating that with continuous activation there was also continuous oxidant production. The specific sources and mechanisms are yet to be thoroughly determined, but our data using apocynin, a NADPH oxidase inhibitor, suggest that increased superoxide generation with chronic activation by tmTNF is largely due to NADPH oxidase based on the 70-75\% suppression of the increased superoxide generation by apocynin. However, this specific inhibition was not $100 \%$, and thus, we have not absolutely ruled out smaller contributions from secondary NO synthase uncoupling due to superoxide/peroxynitrite-mediated tetrahydrobiopterin oxidation, cyclooxigenase activation, or mitochondrial changes. Nevertheless, the conclusion that NADPH oxidase is the primary source of increased oxidant production in tmTNF-expressing endothelial cells is consistent with acute activation of NADPH oxidase by exogenous, soluble TNF [34, 51, 52], which is thought to be mediated by Rac1-associated assembly/activation of NADPH oxidase components [51, 52]. Moreover, our data are consistent with reports that increased oxidants can actually drive further upregulation of expression of NADPH oxidase components [unpubl. data; see also ref. 34]. Of note, the steady increase in cellular oxidants affects signaling, particularly in the different arms of the mitogen-activated protein kinase pathways, in such a way to potentially explain the chronic upregulation of the leukocyte adhesion molecules and the direct angiogenic effects that we observed [53-55]. 
In conclusion, the present study specifically addresses the link between the inflammation and blood vessel growth through the activated endothelium. Our hypothesis that the proinflammatory activated endothelium promotes angiogenesis in a manner that is both leukocyte dependent and leukocyte independent, and also in a growth factor-independent manner in vitro, is not only novel but also of biomedical significance given the increasing number of reports on involvement of angiogenesis in diseases. Although much work remains to be accomplished, the putative link for continuous activated endothelium presented in this study could provide the impetus as an additional target for regulation of angiogenesis in pathological diseases.

\section{Acknowledgments}

This study was supported by the Indiana Center for Vascular Biology and Medicine and the Cryptic Masons Medical Research Foundation. Present address for A. Willuweit: Evotec Neurosciences AG, Zürich, Switzerland and for A. Hilbig: Medizinische Klinik mit Schwerpunkt Hämatologie und Onkologie, Berlin, Germany.

\section{References}

1 Patterson CE, Clauss MA: Signaling of prolonged activation. Perspectives on lung endothelial barrier function; in Patterson CE (ed): Advances in Molecular and Cellular Biology. Amsterdam, Elsevier, 2004, vol 35, pp 165204.

2 Risau W: Mechanisms of angiogenesis. Nature 1997;386:671-674.

3 Carmeliet P: Angiogenesis in health and disease. Nat Med 2003;9:653-660.

4 Orsida BE, Ward C, Li X, Bish R, Wilson JW, Thien F, Walters EH: Effect of a long-acting beta2-agonist over three months on airway wall vascular remodeling in asthma. Am J Respir Crit Care Med 2001;164:117-121.

5 McCourt M, Wang JH, Sookhai S, Redmond HP: Proinflammatory mediators stimulate neutrophil-directed angiogenesis. Arch Surg 1999;134:1325-1331; discussion 1331-1322.

6 Seo KH, Ko HM, Choi JH, Jung HH, Chun YH, Choi IW, Lee HK, Im SY: Essential role for platelet-activating factor-induced NFkappaB activation in macrophage-derived angiogenesis. Eur J Immunol 2004;34:2129_ 2137.

7 Schruefer R, Lutze N, Schymeinsky J, Walzog $\mathrm{B}$ : Human neutrophils promote angiogenesis by a paracrine feedforward mechanism involving endothelial interleukin-8. Am J Physiol Heart Circ Physiol 2005;288:H1186H1192.

8 Sugano M, Tsuchida K, Tomita H, Makino N: Increased proliferation of endothelial cells with overexpression of soluble TNF-alpha receptor I gene. Atherosclerosis 2002;162:7784.

9 Koolwijk P, van Erck MG, de Vree WJ, Vermeer MA, Weich HA, Hanemaaijer R, van Hinsbergh VW: Cooperative effect of TNFalpha, bFGF, and VEGF on the formation of tubular structures of human microvascular endothelial cells in a fibrin matrix. Role of urokinase activity. J Cell Biol 1996;132:1177-1188.

10 Feldman AM, McTiernan C: Is there any future for tumor necrosis factor antagonists in chronic heart failure? Am J Cardiovasc Drugs 2004;4:11-19.

Endothelial Activation Directly Links

Angiogenesis and Inflammation
11 Hurlimann D, Forster A, Noll G, Enseleit F, Chenevard R, Distler O, Bechir M, Spieker LE, Neidhart M, Michel BA, et al: Anti-tumor necrosis factor-alpha treatment improves endothelial function in patients with rheumatoid arthritis. Circulation 2002;106:2184-2187.

12 Madhotra R, Gilmore IT: Recent developments in the treatment of alcoholic hepatitis. QJM 2003;96:391-400.

13 Maksimowicz-McKinnon K, Bhatt DL, Calabrese LH: Recent advances in vascular inflammation: C-reactive protein and other inflammatory biomarkers. Curr Opin Rheumatol 2004; 16:18-24.

14 Neurath MF, Fuss I, Pasparakis M, Alexopoulou L, Haralambous S, Meyer zum Buschenfelde KH, Strober W, Kollias G: Predominant pathogenic role of tumor necrosis factor in experimental colitis in mice. Eur J Immunol 1997;27:1743-1750.

15 Barath P, Fishbein MC, Cao J, Berenson J, Helfant RH, Forrester JS: Tumor necrosis factor gene expression in human vascular intimal smooth muscle cells detected by in situ hybridization. Am J Pathol 1990;137:503-509.

16 Botchkina GI, Meistrell ME 3rd, Botchkina IL, Tracey KJ: Expression of TNF and TNF receptors (p55 and p75) in the rat brain after focal cerebral ischemia. Mol Med 1997;3: 765-781.

17 Brosnan CF, Cannella B, Battistini L, Raine CS: Cytokine localization in multiple sclerosis lesions: correlation with adhesion molecule expression and reactive nitrogen species. Neurology 1995;45:S16-S21.

18 Clauss M, Sunderkotter C, Sveinbjornsson B, Hippenstiel S, Willuweit A, Marino M, Haas E, Seljelid R, Scheurich P, Suttorp N, et al: A permissive role for tumor necrosis factor in vascular endothelial growth factor-induced vascular permeability. Blood 2001;97:13211329.
19 Eissner G, Kohlhuber F, Grell M, Ueffing M, Scheurich P, Hieke A, Multhoff G, Bornkamm GW, Holler E: Critical involvement of transmembrane tumor necrosis factor-alpha in endothelial programmed cell death mediated by ionizing radiation and bacterial endotoxin. Blood 1995;86:4184-4193.

20 Freyer D, Manz R, Ziegenhorn A, Weih M, Angstwurm K, Docke WD, Meisel A, Schumann RR, Schonfelder G, Dirnagl U, et al: Cerebral endothelial cells release TNF-alpha after stimulation with cell walls of Streptococcus pneumoniae and regulate inducible nitric oxide synthase and ICAM-1 expression via autocrine loops. J Immunol 1999; 163:43084314.

21 Selmaj K, Raine CS, Cannella B, Brosnan CF: Identification of lymphotoxin and tumor necrosis factor in multiple sclerosis lesions. J Clin Invest 1991;87:949-954.

22 Valen G, Erl W, Eriksson P, Wuttge D, Paulsson G, Hansson GK: Hydrogen peroxide induces mRNA for tumour necrosis factor alpha in human endothelial cells. Free Radic Res 1999;31:503-512.

23 Steffen BJ, Breier G, Butcher EC, Schulz M, Engelhardt B: ICAM-1, VCAM-1, and MAdCAM-1 are expressed on choroid plexus epithelium but not endothelium and mediate binding of lymphocytes in vitro. Am J Pathol 1996;148:1819-1838.

24 Engelhardt B, Laschinger M, Schulz M, Samulowitz U, Vestweber D, Hoch G: The development of experimental autoimmune encephalomyelitis in the mouse requires alpha4-integrin but not alpha4beta7-integrin. J Clin Invest 1998;102:2096-2105.

25 Kiefer F, Anhauser I, Soriano P, Aguzzi A, Courtneidge SA, Wagner EF: Endothelial cell transformation by polyomavirus middle $\mathrm{T}$ antigen in mice lacking Src-related kinases. Curr Biol 1994;4:100-109.

26 Decoster E, Vanhaesebroeck B, Vandenabeele P, Grooten J, Fiers W: Generation and biological characterization of membrane-bound, uncleavable murine tumor necrosis factor. $\mathrm{J}$ Biol Chem 1995;270:18473-18478. 
27 Willuweit A, Sass G, Schoneberg A, Eisel U, Tiegs G, Clauss M: Chronic inflammation and protection from acute hepatitis in transgenic mice expressing TNF in endothelial cells. J Immunol 2001;167:3944-3952.

28 Morgenstern JP, Land H: Advanced mammalian gene transfer: high titre retroviral vectors with multiple drug selection markers and a complementary helper-free packaging cell line. Nucleic Acids Res 1990;18:3587-3596.

29 Markowitz D, Goff S, Bank A: A safe packaging line for gene transfer: separating viral genes on two different plasmids. J Virol 1988;62: $1120-1124$.

30 Cominacini L, Pasini AF, Garbin U, Davoli A, Tosetti ML, Campagnola M, Rigoni A, Pastorino AM, Lo Cascio V, Sawamura T: Oxidized low density lipoprotein (ox-LDL) binding to ox-LDL receptor-1 in endothelial cells induces the activation of NF-kappaB through an increased production of intracellular reactive oxygen species. J Biol Chem 2000;275: 12633-12638.

31 Keller A, Mohamed A, Drose S, Brandt U, Fleming I, Brandes RP: Analysis of dichlorodihydrofluorescein and dihydrocalcein as probes for the detection of intracellular reactive oxygen species. Free Radic Res 2004;38: 1257-1267.

32 Issbrucker K, Marti HH, Hippenstiel S, Springmann G, Voswinckel R, Gaumann A, Breier G, Drexler HC, Suttorp N, Clauss M: p38 MAP kinase - A molecular switch between VEGFinduced angiogenesis and vascular hyperpermeability. Faseb J 2003;17:262-264.

33 Passaniti A, Taylor RM, Pili R, Guo Y, Long PV, Haney JA, Pauly RR, Grant DS, Martin GR: A simple, quantitative method for assessing angiogenesis and antiangiogenic agents using reconstituted basement membrane, heparin, and fibroblast growth factor. Lab Invest 1992;67:519-528.

34 Gertzberg N, Neumann P, Rizzo V, Johnson A: NAD $(\mathrm{P}) \mathrm{H}$ oxidase mediates the endothelial barrier dysfunction induced by TNF-alpha. Am J Physiol Lung Cell Mol Physiol 2004;286: L37-L48.

35 Schneider C: Chemistry and biology of vitamin E. Mol Nutr Food Res 2005;49:7-30.
36 Stolk J, Hiltermann TJ, Dijkman JH, Verhoeven AJ: Characteristics of the inhibition of NADPH oxidase activation in neutrophils by apocynin, a methoxy-substituted catechol. Am J Respir Cell Mol Biol 1994;11:95-102.

37 Jadeski LC, Lala PK: Nitric oxide synthase inhibition by $N(G)$-nitro- $L$-arginine methyl ester inhibits tumor-induced angiogenesis in mammary tumors. Am J Pathol 1999;155:13811390.

38 Lucerna M, Mechtcheriakova D, Kadl A, Schabbauer G, Schafer R, Gruber F, Koshelnick Y, Muller HD, Issbrucker K, Clauss $\mathrm{M}$, et al: NAB2, a corepressor of EGR-1, inhibits vascular endothelial growth factor-mediated gene induction and angiogenic responses of endothelial cells. J Biol Chem 2003;278 11433-11440.

39 Kruger EA, Duray PH, Tsokos MG, Venzon DJ, Libutti SK, Dixon SC, Rudek MA, Pluda J, Allegra C, Figg WD: Endostatin inhibits microvessel formation in the ex vivo rat aortic ring angiogenesis assay. Biochem Biophys Res Commun 2000;268:183-191.

40 Young PE, Baumhueter S, Lasky LA: The sialomucin CD34 is expressed on hematopoietic cells and blood vessels during murine development. Blood 1995;85:96-105.

41 Barath P, Fisbein MC, Cao J, Berenson J, Helfant RH, Forrester JS: Detection and localization of tumor necrosis factor in human atheroma. Am J Cardiol 1990;65:297-302.

42 McKenney JK, Weiss SW, Folpe AL: CD31 expression in intratumoral macrophages: a potential diagnostic pitfall. Am J Surg Pathol 2001;25:1167-1173.

43 Bagley RG, Walter-Yohrling J, Cao X, Weber W, Simons B, Cook BP, Chartrand SD, Wang C, Madden SL, Teicher BA: Endothelial precursor cells as a model of tumor endothelium characterization and comparison with mature endothelial cells. Cancer Res 2003;63:58665873.

44 Mantovani A: Tumor-associated macrophages in neoplastic progression - A paradigm for the in vivo function of chemokines. Lab Invest 1994; 71:5-16.

45 Nehls V, Schuchardt E, Drenckhahn D: The effect of fibroblasts, vascular smooth muscle cells, and pericytes on sprout formation of endothelial cells in a fibrin gel angiogenesis system. Microvasc Res 1994;48:349-363.
46 Koblizek TI, Weiss C, Yancopoulos GD, Deutsch U, Risau W: Angiopoietin-1 induces sprouting angiogenesis in vitro. Curr Biol 1998;8:529-532.

47 Canault M, Peiretti F, Mueller C, Kopp F, Morange $\mathrm{P}$, Rihs $\mathrm{S}$, Portugal $\mathrm{H}$, Juhan-Vague I, Nalbone G: Exclusive expression of transmembrane TNF-alpha in mice reduces the inflammatory response in early lipid lesions of aortic sinus. Atherosclerosis 2004; 172:211-218.

48 Gho YS, Kleinman HK, Sosne G: Angiogenic activity of human soluble intercellular adhesion molecule-1. Cancer Res 1999;59:51285132.

49 Nakao S, Kuwano T, Ishibashi T, Kuwano M, Ono M: Synergistic effect of TNF-alpha in soluble VCAM-1-induced angiogenesis through alpha 4 integrins. J Immunol 2003;170:57045711.

50 Colavitti R, Pani G, Bedogni B, Anzevino R, Borrello S, Waltenberger J, Galeotti T: Reactive oxygen species as downstream mediators of angiogenic signaling by vascular endothelial growth factor receptor-2/KDR. J Biol Chem 2002;277:3101-3108

51 Takai Y, Sasaki T, Matozaki T: Small GTPbinding proteins. Physiol Rev 2001;81:153208.

52 Chen XL, Zhang Q, Zhao R, Medford RM: Superoxide, $\mathrm{H}_{2} \mathrm{O}_{2}$, and iron are required for TNF-alpha-induced MCP-1 gene expression in endothelial cells: role of Rac1 and NADPH oxidase. Am J Physiol Heart Circ Physiol 2004;286:H1001-H1007.

53 Griendling KK, Sorescu D, Lassegue B, UshioFukai M: Modulation of protein kinase activity and gene expression by reactive oxygen species and their role in vascular physiology and pathophysiology. Arterioscler Thromb Vasc Biol 2000;20:2175-2183.

54 Lee K, Esselman WJ: Inhibition of PTPs by $\mathrm{H}(2) \mathrm{O}(2)$ regulates the activation of distinct MAPK pathways. Free Radic Biol Med 2002; 33:1121-1132.

55 Usatyuk PV, Vepa S, Watkins T, He D, Parinandi NL, Natarajan V: Redox regulation of reactive oxygen species-induced p38 MAP kinase activation and barrier dysfunction in lung microvascular endothelial cells. Antioxid Redox Signal 2003;5:723-730. 